\title{
PENGETAHUAN ILMIAH BERBASIS BUDAYA DAN KEARIFAN LOKAL DI KARIMUNJAWA UNTUK MENUMBUHKAN SOFT SKILLS KONSERVASI
}

\author{
Sudarmin ${ }^{1)}$, Zaenuri Mastur ${ }^{2)}$, Parmin $^{3)}$ \\ Faculty Mathematic and Science - Semarang of State University \\ Email: darsudarmin@yahoo.com
}

\begin{abstract}
This study aims to reconstruct a new theory concerning the basic science of science based on local wisdom in Karimunjawa as a vehicle to grow Soft skills conservation. This study is a qualitative research etnosains with community and environmental settings in Karimun Islands. The study subjects consisted of fishermen, tour guides, as well as the homestay owners . Retrieval of data through interviews, direct observation, and questionnaires. The data obtained and verified, is reduced , and conceptualization. The focus of research is the moral message of conservation that is placed on the bulletin board in the Karimunjawa National Park ; Manggrove forest, beach Karimunjawa. In this study also revealed the types of indigenous flora and fauna, as well as soft skills and habits of society Publications. The results of the study found that the value of soft skills such karimunjawa community is working hard, persevering, mutual cooperation . religious , friendly, caring and nurturing environment. The results showed that the conservation of moral message posted on the bulletin board in the Karimunjawa National Park is the conservation of sea turtles, marine fish, marine life, and a variety of coral reef Karimunjawa results also found that local knowledge is still maintained in the plant community dewandaru, Setigi, kalimosodho, soft skills and love of the nation, caring environment, religous, friendly, work hard, and democratic.
\end{abstract}

Keywords: Scientific knowledge, local wisdom conservation

\begin{abstract}
Abstrak: Penelitian ini bertujuan untuk merekonstruksi sebuah teori baru mengenai ilmu pengetahuan dasar sains berdasarkan kearifan lokal di Karimunjawa sebagai wahana untuk mengembangkan soft skill konservasi. Penelitian ini merupakan penelitian kualitatif dengan pengaturan masyarakat dan lingkungan di Kepulauan Karimun. Subyek penelitian terdiri dari nelayan, pemandu wisata, serta pemilik homestay. Pengambilan data melalui wawancara, observasi langsung, dan kuesioner. Data yang diperoleh dan diverifikasi, dikurangi, dan konseptualisasi. Fokus penelitian adalah pesan moral konservasi yang ditempatkan di papan buletin di Taman Nasional Karimunjawa; Hutan Manggrove, pantai Karimunjawa. Dalam penelitian ini juga terungkap jenisjenis flora dan fauna pribumi, serta soft skill dan kebiasaan masyarakat Publikasi. Hasil penelitian menemukan bahwa nilai soft skill seperti komunitas karimunjawa sedang bekerja keras, tekun, gotong royong. Religius, ramah, peduli dan peduli. Hasil penelitian menunjukkan bahwa pelestarian pesan moral yang dimuat di papan buletin di Taman Nasional Karimunjawa adalah konservasi penyu, ikan laut, kehidupan laut, dan berbagai hasil terumbu karang Karimunjawa juga menemukan bahwa pengetahuan lokal masih terjaga di Komunitas tanaman dewandaru, Setigi, kalimosodho, soft skill dan cinta bangsa, peduli lingkungan, religous, ramah, kerja keras, dan demokratis.
\end{abstract}

Kata Kunci: Pengetahuan ilmiah, konservasi kearifan lokal

\section{PEndahuluan}

Karimunjawa merupakan Taman Nasional Cagar Laut sejak tahun 1988. Karimunjawa sebagai cagar laut, maka masyarakat lokal telah memiliki etika moral, sosial, budaya, dan pengetahuan sains lokal (indegenous science) sebagai kearifan lokal yang unik dan mendarah daging sebagai pola perilaku dalam menjaga lingkungan berbagai biota laut, terumbu karang, dan fauna. Kenyataannya saat ini, sains masyarakat berbasis buadaya lokal dan kearifan lokal akan hal-hal yang unik di belum banyak diteliti dan diungkap. bahkan dimanfaatkansebagai sumber belajar dalam menanamkan konten dan konteks Soft skills konservasi pada pembelajaran sains. Olehkarenanya, Penelitian ini dimaksudkan untuk merekonstruksi pengetahuan sains ilmiah berbasis kearifan lokal sebagai wahana menumbuhkan soft skill konservasi berbagai biota laut, flora, fauna, Magrove, tanaman khas dan nilai-nilai positip yang terdapat pada masyarakat dan tokoh masyarakat yang terpelihara sebagai kearifan lokal.

Penelitian ini diharapkan memiliki kontribusi bidang pengetahuan dasar yaitu menemukan 
grounded theory berkaitan rekonstruksi pengetahuan sains ilmiah berbasis kearifan lokal. Hasil penelitian ini dapat diharapkan dapat sebagai wahana memperkaya pengetahuan ilmiah mengenai nilainilai soft skills konservasi bagi generasi penerus. Konservasi merupakan misi dan visi di Unnes, sehingga penelitian ini erat dengan perwujudan misi dan visi Unnes.

Pentingnya membangun (rekontruk-si) pengetahuan sains ilmiah berbasis kearifan lokal di Karimunjawa, karena banyak masyarakat kepulauan Karimunjawa telah menerapkan pola perilaku konservasi berbagai biota laut dan terumbu karang, flora, dan fauna dalam kehidupannya, tetapi belum terformulasikan dan terkonsepkan secara ilmiah sebagai sumber pembelajaran. Pe-ngetahuan sains ilmiah berbasis kearifan lokal tersebut berkontribusi penyediaan sumber belajae sains.

Transformasi dan rekonstruksi pe-ngetahuan sains masyarakat menjadi pengetahuan sains ilmiah sebagai bentuk upaya mewujudkan konservasi terhadap lingkunan ekosistem, etnobotani, dan biota kelautan telah dilakukan oleh Jegele (2002, dan Duit (2007). Indonesia juga mulai menglobalkan sains masyarakat sebagai penelitian grounded thery dan sekaligus membangun teori baru sebagai sumber belajar telah dilakukan di Unnes.

Rujukan mengenai rekonstruksi pengetahuan sains asli menjadi sains ilmiah untuk membangun grounded theory dan memperkaya pengetahuan sains ilmiah tersebut, maka pada penelitian ini masalah yang diteliti adalah (a) menemukan jenis atribut penelitian pengetahun sains asli masyarakat dan kearifan lokal yang dapat ditemukan di Kepulauan Karimunjawa yang mengandung sains ilmiah, (b) memfor-mulasikan pengetahuan sains ilmiah berbasis kearifan lokal dalam pembelajaran sains.

Penelitian ini secara praktis bermanfaat bagi (a) mahasiswa calon guru sains (IPA) mengenai model pembelajaran sains berbasis kearifan lokal yang kontekstual; sehingga hasil pengembangan sumber belajar ini mampu memperkaya pengetahuan sains ilmiah yang berorientasi etnosains, serta meningkatkan kreativitas dan motivasi calon guru sains (b) mahasiswa calon guru sains, karena mereka memperoleh pengalaman mengenai model pembelajaran sains pembelajaran karakter berbasis kearifan lokal.

\section{METODE}

Jenis penelitian ini menggunakan pendekatan kualitatif fenomologis etnosains yaitu suatu kajian tentang sistem pengetahuan yang diorganisasi dari budaya masyarakat dan kearifan lokal berkaitan fenomena dan kejadian-kejadian yang berhubungan alam dan kearifan lokal mengacu pada Battiste, (2005) dan Creswell (2009). Penelitian ini dilakukan melalui pengamatan yang diarahkan pada hutan Manggrove, laut dan pantai-pantai di kawasan Karimunjawa; tempat bernilai religious dan dikeramtakan. Penelitian ini juga diarahkan pada berbagai kegiatan dan perilaku dari para nelayan, masyarkat penghuni kepulauan Karimunjawa, tokoh masyarakat, pemilik home stay, tokoh agama, dan guru.

Peneliti dalam penelitian ini menjadi instrumen utama agar dapat mengumpulkan data pengetahuan sains asli masyarakat lokal sebanyak mungkin, dilanjutkan verifikasi, rekonstruksi, formulasi, dan konseptualisasi dan dokumentasi sehingga menjadi sains ilmiah yang terformalkan.. Analisis data secara deskriptif juga dilakukan untuk data transformasi sains asli masyarakat dan kearifan local menjadi sains ilmiah. untuk memperkaya sains ilmiah berbasis budaya dan kearifan local sebagai upaya menumbuhkan Soft skill konservasi.

\section{HASIL DAN PEMBAHASAN}

\section{Hasil Eksplorasi Soft Skills Konservasi di Kancah Penelitian}

Hasil wawancara dengan saudara Ghofur (32 tahun) sebagai pemandu wisata dan analisis dokumenatasi kepulauan Karimunjawa di-ketahui kepulauan karimunjawa terdapat 27 kepulauan yaitu 5 kepulauan berpenghuni dan 22 tidak berpenghuni. Pada penelitian ini, yang dijadikan kancah penelitian adalah kepulauan yang berpenghuni yaitu desa Karimunjawa Darat dan Kamujan, dan kepulauan tidak berpenghuni yaitu pulau Menjangan besar dan kecil, Merica, Kerakal, Cemara, Geleang, dan Seruni. Pada penelitian yang menjadi fokus penelitian adalah papan informasi dan kearifan lokal yang berkaitan kawasan konservasi Taman Nasional Karimunjawa, biota laut, kearifan lokal dari flora dan fauna, terumbu karang, keanekargaman ikan, dan hutan Mangrove. Hasil eksplorasi, observasi pada 
wilayah penelitian ini, maka ditemukan pesan-pesan nilai soft skills konservasi seperti disajikan Tabel 1.

Tabel 1. Pesan dan Nilai soft skills yang terpasang di tempat penelitian

\begin{tabular}{|c|c|c|c|}
\hline No & $\begin{array}{c}\text { Lokasi } \\
\text { Penelitian }\end{array}$ & $\begin{array}{l}\text { Isi Konten } \\
\text { Konservasi }\end{array}$ & $\begin{array}{c}\text { Kategori } \\
\text { Soft Skill } \\
\text { Konservasi } \\
\text { (Sains } \\
\text { Ilmiah) }\end{array}$ \\
\hline \multirow[t]{3}{*}{1} & \multirow[t]{3}{*}{$\begin{array}{l}\text { Armada } \\
\text { Kedatangan } \\
\text { dan } \\
\text { pemberangkata } \\
\text { n penumpang. }\end{array}$} & $\begin{array}{l}\text { Sambutlah } \\
\text { tamu dengan } \\
\text { ramah } \\
\text { Senyum dan } \\
\text { bersahabat }\end{array}$ & $\begin{array}{l}\text { Budaya dan } \\
\text { moral }\end{array}$ \\
\hline & & $\begin{array}{l}\text { Keutuhan dan } \\
\text { keindahan } \\
\text { alami } \\
\text { merupakan } \\
\text { nafas wisata } \\
\text { Karimunjawa }\end{array}$ & $\begin{array}{l}\text { Cinta alam } \\
\text { dan peduli } \\
\text { lingkungan }\end{array}$ \\
\hline & & $\begin{array}{l}\text { Mari kita } \\
\text { wujudkan } \\
\text { Karimunjawa } \\
\text { sebagai desa } \\
\text { wisata yang } \\
\text { ramah, bersih, } \\
\text { dan nyaman }\end{array}$ & $\begin{array}{l}\text { Cinta bangsa } \\
\text { dan peduli } \\
\text { lingkungan, } \\
\text { dan moral. }\end{array}$ \\
\hline \multirow[t]{2}{*}{2} & \multirow[t]{2}{*}{$\begin{array}{l}\text { Pembayaran } \\
\text { Tiket dan } \\
\text { Papan } \\
\text { Informasi di } \\
\text { dekat Anjungan } \\
\text { Karimunjawa }\end{array}$} & $\begin{array}{l}\text { Terima kasih } \\
\text { atas partisipasi } \\
\text { anda } \\
\text { membayar tiket } \\
\text { masuk kawasan } \\
\text { Taman } \\
\text { Nasional } \\
\text { Karimunjawa }\end{array}$ & $\begin{array}{l}\text { Cinta bangsa } \\
\text { dan flora, } \\
\text { fauna, dan } \\
\text { tanggung } \\
\text { jawab. }\end{array}$ \\
\hline & & $\begin{array}{l}\text { Tiket yang } \\
\text { anda bayar } \\
\text { berguna untuk } \\
\text { menjaga } \\
\text { kelestarian } \\
\text { Alam dan Laut } \\
\text { Karimunjawa }\end{array}$ & $\begin{array}{l}\text { Peduli } \\
\text { lingkungan, } \\
\text { hutan, dan } \\
\text { laut }\end{array}$ \\
\hline \multirow[t]{3}{*}{3} & \multirow[t]{3}{*}{$\begin{array}{l}\text { Hutan Taman } \\
\text { Nasional } \\
\text { Karimunjawa } \\
\text { dan Papan } \\
\text { informasi di } \\
\text { desa } \\
\text { Karimunjawa }\end{array}$} & $\begin{array}{l}\text { Wujudkan } \\
\text { Karimunjawa } \\
\text { sebagai } \\
\text { kecamatan } \\
\text { yang aman, } \\
\text { nyaman, tertib } \\
\text { dan alami }\end{array}$ & $\begin{array}{l}\text { Peduli } \\
\text { lingkungan, } \\
\text { moral, dan } \\
\text { budaya }\end{array}$ \\
\hline & & $\begin{array}{l}\text { Sambutlah } \\
\text { Tamu dengan } \\
\text { ramah, senyum, } \\
\text { dan } \\
\text { bersahabat. }\end{array}$ & $\begin{array}{l}\text { Kearifan } \\
\text { lokal, } \\
\text { budaya dan } \\
\text { moral }\end{array}$ \\
\hline & & $\begin{array}{l}\text { Keutuhan dan } \\
\text { Keindahan } \\
\text { alami } \\
\text { merupakan } \\
\text { nafas wisata } \\
\text { Karimu-njawa. }\end{array}$ & $\begin{array}{l}\text { Peduli } \\
\text { lingkungan, } \\
\text { moral dan } \\
\text { budaya }\end{array}$ \\
\hline 4 & $\begin{array}{l}\text { Kawasan } \\
\text { Kepulauan dan } \\
\text { Laut } \\
\text { Karimunjawa }\end{array}$ & $\begin{array}{l}\text { Dilarang } \\
\text { membuang } \\
\text { sampah serta } \\
\text { bahan } \\
\text { pencemar ke } \\
\text { Laut }\end{array}$ & $\begin{array}{l}\text { Peduli } \\
\text { lingkungan, } \\
\text { konservasi } \\
\text { biota laut, } \\
\text { terumbu } \\
\text { karang, dan }\end{array}$ \\
\hline
\end{tabular}

\begin{tabular}{|c|c|c|c|}
\hline No & $\begin{array}{c}\text { Lokasi } \\
\text { Penelitian }\end{array}$ & $\begin{array}{l}\text { Isi Konten } \\
\text { Konservasi }\end{array}$ & $\begin{array}{c}\text { Kategori } \\
\text { Soft Skill } \\
\text { Konservasi } \\
\text { (Sains } \\
\text { Ilmiah) }\end{array}$ \\
\hline & & $\begin{array}{l}\text { Do not Litter, } \\
\text { Trash Left, } \\
\text { waste, and } \\
\text { other pollution } \\
\text { at Sea }\end{array}$ & $\begin{array}{l}\text { flora dan } \\
\text { fauna. }\end{array}$ \\
\hline 5 & Kawasan laut & $\begin{array}{l}\text { Ambillah } \\
\text { kenangan } \\
\text { dengan foto-mu } \\
\text { dan jangan } \\
\text { mengambil } \\
\text { sesuatu di Alam } \\
\text { sebagai } \\
\text { Kenangan }\end{array}$ & $\begin{array}{l}\text { Peduli } \\
\text { lingkungan, } \\
\text { flora, dan } \\
\text { fauna }\end{array}$ \\
\hline \multirow[t]{3}{*}{6} & \multirow[t]{3}{*}{$\begin{array}{l}\text { Papan } \\
\text { informasi di } \\
\text { Kantaor } \\
\text { Kecamatan } \\
\text { Karimunjawa. }\end{array}$} & $\begin{array}{l}\text { Mari kita } \\
\text { bangun } \\
\text { Karimunjawa } \\
\text { sebagai } \\
\text { kecamatan } \\
\text { wisata }\end{array}$ & $\begin{array}{l}\text { Cinta bangsa } \\
\text { dan peduli } \\
\text { lingkungan. }\end{array}$ \\
\hline & & $\begin{array}{l}\text { Pengunjung } \\
\text { adalah tamu } \\
\text { kita, sambutlah } \\
\text { dengan ramah } \\
\text { dan ber- } \\
\text { sahabat, dan } \\
\text { hindari } \\
\text { merusak objek } \\
\text { kunjungan anda }\end{array}$ & $\begin{array}{l}\text { Kearifan } \\
\text { lokal moral, } \\
\text { budaya, dan } \\
\text { peduli } \\
\text { lingkungan. }\end{array}$ \\
\hline & & $\begin{array}{l}\text { Menata } \\
\text { lingkungan, } \\
\text { rumah, desa } \\
\text { dan kecamatan } \\
\text { rapi, bersih, } \\
\text { indah }\end{array}$ & $\begin{array}{l}\text { Cinta bangsa } \\
\text { dan peduli } \\
\text { lingkungan }\end{array}$ \\
\hline
\end{tabular}

Pesan moral yang tersajikan Tabel 1, diketahui bahwa papan tersebut secara ilmiah mengandung makna bahwa masyarakat dan pengunjung wisata di Karimunjawa harus memiliki karakter kesantunan dan kesopanan, bermoral dan berbudi pekerti mulia, cinta bangsa dan lingkungan, dan tanggung jawab. Adapun konservasi yang perlu diperhatikan dan ditularkan kepada mahasiswa adalah konservasi lingkungan laut, hutan, air, dan kehidupan laut dan hutan Magrove. Pada kegiatan eksplorasi dan observasi di beberapa kepulauan karimunjawa, maka tim peneliti mengadakan pengamatan biota laut, terumbu karang, jenis flora dan fauna, ling-kungan, dan pesan konservasinya disajikan pada Tabel 2. 
Tabel 2. Rekap Pesan Konservasi di Lokasi Penelitian

\begin{tabular}{|c|c|c|c|}
\hline No & $\begin{array}{c}\text { Lokasi dan } \\
\text { tempat } \\
\text { Penelitian }\end{array}$ & $\begin{array}{c}\text { Isi Konten Soft } \\
\text { skills } \\
\text { konservasi }\end{array}$ & $\begin{array}{c}\text { Kategori soft } \\
\text { skill yang } \\
\text { dikembangkan }\end{array}$ \\
\hline 1 & $\begin{array}{l}\text { Kepulaun } \\
\text { Menjangan } \\
\text { Besar }\end{array}$ & $\begin{array}{l}\text { Penyu } \\
\text { dilindungi, } \\
\text { dilestarikan, dan } \\
\text { dimanfaatkan }\end{array}$ & $\begin{array}{l}\text { Konservasi } \\
\text { Penyu. }\end{array}$ \\
\hline 2 & $\begin{array}{l}\text { Kepulauan } \\
\text { Merica, } \\
\text { Kerakal, } \\
\text { Cemara }\end{array}$ & $\begin{array}{l}\text { Anda mau } \\
\text { menyelam : } \\
\text { 1. Hati-hati } \\
\text { dalam } \\
\text { pengambila } \\
\text { n foto biota } \\
\text { 2. Jangan } \\
\text { menginjak, } \\
\text { memegang } \\
\text { terumbu } \\
\text { karang, dan } \\
\text { mengaduk } \\
\text { aduk pasir }\end{array}$ & $\begin{array}{l}\text { Konservasi } \\
\text { biota laut, } \\
\text { terumbu karang, } \\
\text { dan cinta } \\
\text { lingkungan }\end{array}$ \\
\hline \multirow[t]{10}{*}{3} & \multirow{5}{*}{$\begin{array}{l}\text { Hutan Magrove } \\
\text { (Dipasang di } \\
\text { sepanjang } \\
\text { hutan Taman } \\
\text { Nasional } \\
\text { Konservasi } \\
\text { Karimunjawa) }\end{array}$} & $\begin{array}{l}\text { Hutan } \\
\text { merupakan } \\
\text { sumber air } \\
\text { bersih }\end{array}$ & $\begin{array}{l}\text { Konservasi } \\
\text { hutan dan air }\end{array}$ \\
\hline & & $\begin{array}{l}\text { Air ini } \\
\text { merupakan hasil } \\
\text { resapan hutan } \\
\text { kita }\end{array}$ & Konservasi air \\
\hline & & $\begin{array}{l}\text { Jika hutan rusak, } \\
\text { maka airpun } \\
\text { mengjilang, } \\
\text { kehidupan } \\
\text { punah }\end{array}$ & $\begin{array}{l}\text { Konservasi } \\
\text { hutan dan air }\end{array}$ \\
\hline & & $\begin{array}{l}\text { Mari jaga hutan } \\
\text { kita, sekarang }\end{array}$ & $\begin{array}{l}\text { Konservasi } \\
\text { hutan }\end{array}$ \\
\hline & & $\begin{array}{l}\text { Awas bahaya } \\
\text { kebakaran, } \\
\text { hindari bersih } \\
\text { lingkungan } \\
\text { dengan mem- } \\
\text { bakar, pastikan } \\
\text { putung rokok } \\
\text { anda sudah } \\
\text { padam sebelum } \\
\text { membuang. }\end{array}$ & $\begin{array}{l}\text { Konservasi } \\
\text { hutan dan } \\
\text { peduli } \\
\text { lingkungan }\end{array}$ \\
\hline & \multirow{5}{*}{$\begin{array}{l}\text { Hutan } \\
\text { Manggrove } \\
\text { (Dipasang di } \\
\text { dalam hutan } \\
\text { Magrove) }\end{array}$} & $\begin{array}{l}\text { Bakauku lestari } \\
\text { hidupku lestari }\end{array}$ & $\begin{array}{l}\text { Konservasi } \\
\text { hutan bakau }\end{array}$ \\
\hline & & $\begin{array}{lr}\text { Bukan } & \text { orang } \\
\text { bijak } & \text { kalau } \\
\text { masih } & \text { merusak } \\
\text { bakau } & \\
\end{array}$ & $\begin{array}{l}\text { Konservasi } \\
\text { moral dan } \\
\text { budaya }\end{array}$ \\
\hline & & $\begin{array}{l}\text { Hutan Bakau } \\
\text { Hidup, ikan laut } \\
\text { hidup, } \\
\text { nelayanpun } \\
\text { hidup. }\end{array}$ & $\begin{array}{l}\text { Konserrvasi } \\
\text { bakau, dan } \\
\text { peduli } \\
\text { lingkungan }\end{array}$ \\
\hline & & $\begin{array}{l}\text { Mangrove } \\
\text { untuk } \\
\text { kehidupan, mari } \\
\text { kita jaga dan } \\
\text { pelihara. }\end{array}$ & $\begin{array}{l}\text { Konserrvasi } \\
\text { Mangrove dan } \\
\text { peduli } \\
\text { lingkungan }\end{array}$ \\
\hline & & $\begin{array}{lr}\text { Sekali } & \text { alam } \\
\text { terjaga } & 1000 \\
\text { manfaat tercipta }\end{array}$ & $\begin{array}{l}\text { Peduli } \\
\text { lingkungan }\end{array}$ \\
\hline 4 & $\begin{array}{ll}\text { Tepi } & \text { laut } \\
\text { Kepulauan } & \end{array}$ & $\begin{array}{l}\text { Masyarakat } \\
\text { ingin hidup }\end{array}$ & $\begin{array}{l}\text { Konservasi } \\
\text { peduli }\end{array}$ \\
\hline
\end{tabular}

\begin{tabular}{|c|c|c|c|}
\hline No & $\begin{array}{c}\text { Lokasi dan } \\
\text { tempat } \\
\text { Penelitian }\end{array}$ & $\begin{array}{c}\text { Isi Konten Soft } \\
\text { skills } \\
\text { konservasi }\end{array}$ & $\begin{array}{c}\text { Kategori soft } \\
\text { skill yang } \\
\text { dikembangkan }\end{array}$ \\
\hline & \multirow[t]{3}{*}{$\begin{array}{l}\text { Kerakal } \\
\text { Karimunjawa }\end{array}$} & $\begin{array}{l}\text { seribu tahun } \\
\text { lagi? Hindari } \\
\text { menangkap dan } \\
\text { mengambil ikan } \\
\text { dengan Bom, } \\
\text { potassium, dan } \\
\text { kompresor. }\end{array}$ & $\begin{array}{l}\text { lingkungan dan } \\
\text { ikan }\end{array}$ \\
\hline & & $\begin{array}{l}\text { Bom dan } \\
\text { Potasium } \\
\text { merusak } \\
\text { terumbu karang, } \\
\text { mematikan ikan } \\
\text { kecil dan besar. }\end{array}$ & $\begin{array}{l}\text { Konservasi } \\
\text { terumbu karang } \\
\text { dan ikan laut. }\end{array}$ \\
\hline & & $\begin{array}{l}\text { Kompresor } \\
\text { merusak } \\
\text { kesehatan anda, } \\
\text { mengakibatkan } \\
\text { lumpuh dan } \\
\text { mati. }\end{array}$ & $\begin{array}{l}\text { Konservasi } \\
\text { lingkungan dan } \\
\text { kesehatan. }\end{array}$ \\
\hline \multirow[t]{3}{*}{5} & \multirow{3}{*}{$\begin{array}{l}\text { Taman } \\
\text { Konservasi } \\
\text { Nasional Hutan } \\
\text { Karimunjawa }\end{array}$} & $\begin{array}{l}\text { Lestari Alamku, } \\
\text { Lestari hutanku }\end{array}$ & $\begin{array}{l}\text { Peduli } \\
\text { lingkungan dan } \\
\text { hutan }\end{array}$ \\
\hline & & $\begin{array}{l}\text { Hutanku lestari, } \\
\text { rakyatku mukti }\end{array}$ & $\begin{array}{l}\text { Konservasi } \\
\text { hutan }\end{array}$ \\
\hline & & $\begin{array}{l}\text { Sekali hutan } \\
\text { terjaga, seribu } \\
\text { manfaat terjaga }\end{array}$ & $\begin{array}{l}\text { Konservasi } \\
\text { hutan }\end{array}$ \\
\hline
\end{tabular}

Pada Tabel 2 diketahui bahwa pesan konservasi untuk penyu, misalnya penyu harus dilindungi, dilestarikan dan dimanfaatkan; sehingga secara sains ilmiah penyu sebagai kearifan lokal yang perlu dilindungi dari kehidupannya. Pelestarian penyu melalui perkembangbiakan, dan dimanfaatkan secara bijak. Hasil penelitian melalui observasi di lokasi pulau tempat penelitian, maka ditemukan pesan konservasi untuk melindungi dan melestarikan, dan memanfaatkan secara bijak untuk kehidupan biota, terumbu karang, ikan besar dan kecil, dan hutan Mangrove di Kemujan Karimunjawa harus memiliki karakter cinta lingkungan dan konservasi hutan bakau, sebab bakau sebagai tempat hidup ikan laut, dan jika ikan laut hidup, maka nelayanpun hidup. bakau atau Mangrove, artinya para pengunjung wisata dan masyarakat.

Pesan dan nilai konservasi hutan Manggrove seperti tertulis: Bukan orang bijak kalau masih merusak dan menebangi hutan Hasil observasi di kepulauan berpenghuni dan tidak berpenghuni juga terdapat pesan-pesan konservasi terkait cinta lingkungan yaitu seperti ditemukan di tepi pantai Karimunjawa, Merica, Menjangan, dan Gosongan seperti Masyarakat ingin hidup seribu tahun lagi? Hindari menangkap dan mengambil ikan dengan 
Bom, potassium, dan kompresor. Hasil penelitian ini menunjukkan pentingnya konservasi hutan bagi masyarakat baik masyarakat asli Karimunjawa maupun wisata.

\section{Hasil dan Pembahasan Eksplorasi Kearifan Lokal di Karimunjawa}

Pada penelitian ini dilakukan ekplorasi mengenai jenis-jenis Kearifan lokal di Kepulauan Karimunjawa. Hasil penelitian beberapa kepulauan Karimunjawa ditemukan beberapa tanaman kearifan lokal yang ada di Kepulaun Karimunjawa, misalnya tanaman dewadaru seperti pada Gambar 1.

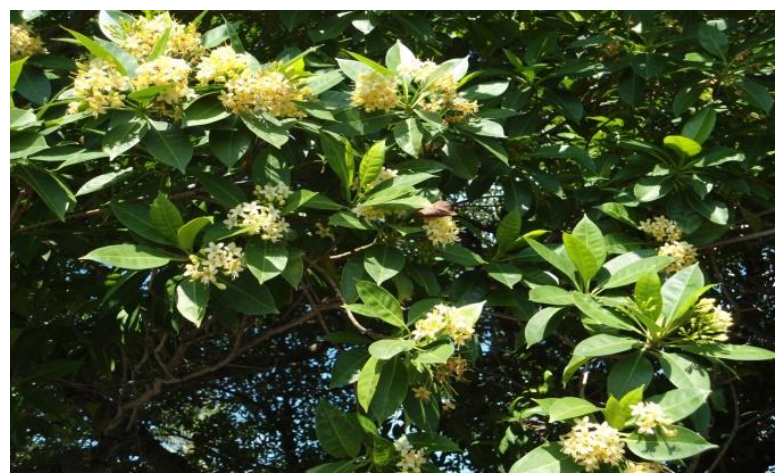

Gambar 1. Tanaman dewandaru berbunga dan berbau wangi di SMP Negeri 1 Karimunjawa sebagai

Kearifan local (Sumber : Dokumentasi pribadi)

Hasil observasi ke beberapa kepulaun Karimunjawa ditemukan tiga jenis tanaman yang sangat langka dan dianggap kearifan lokal di Karimunjawa yaitu tanaman dewadaru, kalimasada dan setigi. Ketiga tanaman tersebut merupakan tanaman khas, menurut hasil wawancara dengan beberapa tokoh masyarakat bahwa kayu dewandaru terletak di Makam Sunan Nyamplungan yang terletak di puncak perbukitan sebelah utara Karimunjawa. Pada pintu gerbang terdapat dua pohon yang sangat besar dan oleh masyarakat mengenalnya sebagai "kayu dewa". Menurut kepercayaan masyarakat bahwa kayu dewandaru memiliki keramat, yaitu siapa yang menyimpan kayu tersebut di rumah maka orang itu terhindar ancaman pencuri atau orang jahat. Kelebihan kayu dewandaru adalah kayu tersebut tidak terapung atau tenggelam. Menurut pengetahuan ilmiah kelebihan kayu dewandaru adalah memiliki berat jenis lebih besar daripada berat jenis air, sehingga tenggelam. Hasil penelitian melalui penga-matan langsung ke hutan Manggrove dite-mukan tanaman kearifan lokal Betah seperti disajikan Gambar 2.

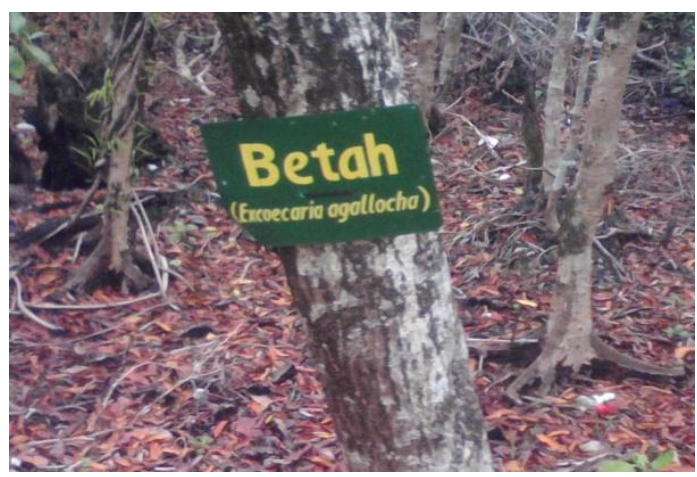

Gambar 2. Tanaman Betah di Hutan Mangrove (dokumen pribadi)

Hasil pengamatan di hutan Manggrove selain ditemukan tanaman kearifan lokal yaitu Betah atau Lumnitzera littorea (Jack) Voig, juga ditemukan 18 jenis tanaman local yang lain, dan 10 diantaranya disajikan Pada Tabel 3.

Tabel 1. Tanaman Mangrove di kawasan Taman Nasional Karimunjawa

\begin{tabular}{|c|l|l|l|}
\hline No & $\begin{array}{c}\text { Nama lokal } \\
\text { (Sains } \\
\text { Masyarakat) }\end{array}$ & $\begin{array}{c}\text { Nama } \\
\text { Indonesia }\end{array}$ & \multicolumn{1}{|c|}{ Nama Spesies } \\
\hline 1 & Kerakas & Paku Laut & $\begin{array}{l}\text { Acrostichum aureum } \\
\text { Linn }\end{array}$ \\
\hline 2 & Tingen & Tingen & $\begin{array}{l}\text { Ceriops decandra } \\
\text { (Griff) }\end{array}$ \\
\hline 3 & Betah & Buta-buta & Excoecaria agalloca \\
\hline 4 & Duduk & Duduk & $\begin{array}{l}\text { Lumnitzera littorea } \\
\text { (Jack) Voigt }\end{array}$ \\
\hline 5 & Setigi & Setigi & Phemphis acidula \\
\hline 6 & Bongko & Bakau & $\begin{array}{l}\text { Rhizophora } \\
\text { mucronata Lmk }\end{array}$ \\
\hline 7 & Dadap laut & Dadap laut & $\begin{array}{l}\text { Clerodendrum } \\
\text { inerme Gaertn }\end{array}$ \\
\hline 9 & Gabusan & $\begin{array}{l}\text { Bako- } \\
\text { bakoan }\end{array}$ & $\begin{array}{l}\text { Scaevola taccada } \\
\text { (Gaertn) }\end{array}$ \\
\hline 10 & Dun garong & Pecut kuda & $\begin{array}{l}\text { Stachytarpheta } \\
\text { jamaicensis }\end{array}$ \\
\hline
\end{tabular}

Hasil analisis dokumenatsi diketahui, secara garis besar tanaman zonasi Mangrove pada kawasan pelestarian dari arah laut ke darat adalah dari jenis Rhizophora apiculata, Rhizophora mocrunata, Rhizophora stylosa, Brugueria gymnorrhiza, Brugueria cylindrica, Xylocarpus granatum, Xylocarpus molluccensis, Ceriops tagal, Lumnitzera littorea, Heritiera littoralis, acanthus ilicifolius, 
Acantus ebracteatus, Acrostichum aureum, acrosticum speciosum.

Pada penelitian ini dilakukan Tanya jawab terhadap beberapa nara sumber sebagai subyek penelitian mengenai tokoh Kyai Nyamplungan. Pada penelitian ini lingkup pertanyaan terkait soft skills nilai-nilai atau ajaran positip dari Kyai Nyamplungan, Nelayan, dan Pemandu Wisata; yangmana datanya disajikankan pada Tabel 3.

\begin{tabular}{|c|c|l|}
\hline No & $\begin{array}{c}\text { Fokus } \\
\text { dan } \\
\text { Subyek } \\
\text { Penelitia } \\
\text { n }\end{array}$ & \multicolumn{1}{|c|}{$\begin{array}{l}\text { Nilai Soft skills positip dari } \\
\text { subyek penelitian }\end{array}$} \\
\hline 1 & $\begin{array}{c}\text { Sunan } \\
\text { Nyamplu } \\
\text { ngan }\end{array}$ & $\begin{array}{l}\text { Religious, cerdas, komunikatif, } \\
\text { tanggung jawab, jujur, toleransi, } \\
\text { kerja keras, dan cinta tanah air dan } \\
\text { agama. }\end{array}$ \\
\hline 2 & Nelayan & $\begin{array}{l}\text { Jujur, bekerja keras, peduli } \\
\text { lingkungan Disiplin, mandiri, } \\
\text { tanggung jawab. }\end{array}$ \\
\hline 3 & $\begin{array}{c}\text { Pemandu } \\
\text { Turis }\end{array}$ & $\begin{array}{l}\text { Ramah, peduli ramah, santun , } \\
\text { peduli lingkungan, tanggung jawab, } \\
\text { disiplin, dan cinta tanah air. }\end{array}$ \\
\hline
\end{tabular}

Tabel 3 terlihat nilai soft skills dan karakter dari tokoh sunan Nyamplungan yaitu religious, tanggung jawab, peduli umat, tokoh sosial, dan sebagai panutan masyrakat. Pada penelitian ini juga dilakukan wawancara pemandu wisata dan sekaligus Nelayan yaitu Ghofur (32 tahun) diperoleh informasi mengenai nilai-nilai karakter yang terlihat oleh Nelayan dan pemandu wisata tersebut adalah tanggung jawab, kerja keras, mandiri, dan kreatif. Sedangkan nilai-nilai karakter yang dimiliki oleh seorang pemandu wisata adalah ramah, jujur, cerdas, kreatif, dan peduli lingkungan.

\section{PENUTUP}

Hasil analisis data penelitian menunjukkan nilai konservasai dan kearifan lokal yang terdapat di masyarakat dan kawasan Karimunjawa adalah nilai konservasi merawat dan memelihara, serta memanfaatkan sumberdaya hayati ikan laut, biota laut, runput laut, penyu, dan berbagai terumbu karang secara bijak, mentaati segala peraturan, himbauan tertulis dalam papan pengumuman konservasi terkait perlindungan hutan dan satwa, pantai, dan tempattempat keramat. Pada penelitian ini terungkap kearifan lokal masih terpelihara seperti dewandaru, setigi, dan kalimosodo. Selain itu juga ditemukan nilai karakter positip dari tokoh dan nelayan, dan pemandu turis yaitu religous, kerja keras, tanggung jawab, dan cinta bangsa, peduli lingkungan, religius dan demokartis.

\section{DAFTAR PUSTAKA}

Adedipe, A. Okuneley, P.A,, Ayinde, I.A. (2004). The Relevance of Local and Indegeneous Knowledge for Nigerian Agriculture. Article for presented at the International Conference on Bridging Scales and Epistemologies: Linking Local Knowledge with Global Science in Multi-Scale Assessments ; March 16-19, 2004, Alexandria, Egypt.

Aikenhead. G. (2002). Renegotion The Culture of School Science. In Improving Science Education: The Contribution of Research. Robin Miler, et al (eds). http://usask.ca/education/people/aikenhead/ren egotition.htm diakses tanggal 2 Mei 2008.

Battiste,M. (2005). Indegenous Knowledge and Pedagogy in First Nations Edu-cation: A Literature Review with Recommendations. INAC, Ottawa: Apamu-wek Institute.

Djulia, E. (2005). Peran Budaya Lokal Dalam Pembentukan Sains. Ringkasan Di-sertasi. UPI Bandung.

Duitt, R. (2007). Science Education Research Internationally: Conception, Research Methods, Domains of Research. Eurasia Journal of Mathematics, Science \& Technology Education, 3(1), 3-15. tersedia: www.ejunste.com diakses tanggal 9 Mei 2008.

Ogawa, M. (2007). Toward a new rationale of science education in a non-western society, European Journal of Science Education, 8, 113-119.

Okebukola, P.A. (1989). Influence of Social-Cultural Factor on Secondary Student' Attitude toward Science. Research in Science Education. 19, 155-164. 
Riggs, E.M. (2004). Field-Based Education and Indegenous Knowledge: Essential Component of Geoscience Education for Native American Communities.: Culture and Comparative Studies. Wiley Periodicals, Inc.

Snively, G, and Corsiglia, J. (2000). Discovering Indegenous Science: Implication for Science Education. USA : John Wiley \& Sons, Inc.

Suastra, I.W. (2005). Merekonstruksi Sains Asli (Indegenous Science) Dalam Rangka Mengembangkan Pendidikan Sains Berbasis Budaya Lokal di Sekolah (Studi Etnosains pada Masyarakat Panglipuran Bali). Ringkasan Disertasi. UPI Bandung.

Sudarmin, Hartono, Sumarni,W. 2009. Merekonstruksi Pengetahuan Sains Asli (Indegenous Science) Berbasis Budaya Jawa Menjadi Sains Ilmiah Sebagaia Wahana Sumber Belajar Sains dan Mengemangkan keterampilan Generik Sains Bagi Calon Guru. Laporan Penelitian Fundamental, LP2M: Unnes.

UNNESCO. 2007. Declaratioon on Science and the Use of Scientific Knowledge, Science for Twenty-First Century. Budapest, Hungary, June 26 - July 1, 1999. ter-sedia: http://www.unesscoorg/science/wcs/eng/decl aration_e.htm. diakses 23 april 2007. 